\title{
KOMUNITAS BURUNG PADA RUANG TERBUKA HIJAU DI KOTA PALU PROVINSI SULAWESI TENGAH
}

\section{(Bird Community at Green Open Space in Palu City Central Sulawesi Province)}

\author{
ABDUl VIKAR ${ }^{1 *}$, AgUS PRIYONO KARTONO ${ }^{2)}$ DAN YeNI A. MULYANI ${ }^{2)}$ \\ 1) Program Studi Konservasi Biodiversitas Tropika, Sekolah Pasca Sarjana Institut Pertanian Bogor, Kampus \\ Darmaga, Bogor, Indonesia 16680 \\ 2) Departemen Konservasi Sumberdaya Hutan \& Ekowisata, Fakultas Kehutanan Institut Pertanian Bogor, Kampus \\ Darmaga, Bogor, Indonesia 16680
}

*Email: abdulvikar89@gmail.com

Diterima 17 Juli 2019 / Disetujui 05 Maret 2020

\begin{abstract}
Open Green Spaces (OGS) is an alternative area for bird community in urban habitat. There are various types and shapes of OGS so that different bird community may utilize different types of OGS. This study aims to identify bird community composition and calculating biodiversity index at five different OGS in Palu urban area. This research was conducted in OGS of city park (hutan kota), grand forest park (Taman Hutan Raya, forest park), Palu city park (Western Palu Park, Southern Palu Park, and Eastern Palu Park). This study use point count method with $25 \mathrm{~m}$ visual radius and $100 \mathrm{~m}$ as a distance point. The observation was conducted for 10 minutes at every point to collect birds data. Vegetation data were observed using partitioned transect method. The number of birds species that has been successfully recorded in five OGS are 58 species from 31 families, and consists of 54 species of resident birds, and 4 species of migratory birds. From those 58 species, there are 10 species are Sulawesi endemic and Walacea. Columbidae is a family that dominating the OGS with the largest members i.e. 9 species (15.5\%), followed by Ardeidae and Cuculidae families each of 4 species (6.9\%). Four of them are protected based on Government Regulations No. 7,1999 and Ministrial Decree No. 106, 2018. Those four species are Haliastur indus, Milvus migrans, Ardea sumatrana, and Loriculus stigmatus. In all observed OGS, there are no IUCN endangered species, however, there are 2 species that categorized as Appendix II CITES (Convention on International Trade in Endangered Species of Wild Fauna and Flora), i.e. Haliastur indus and Milvus migrans. The highest birds biodiversity index $\left(H^{\prime}\right)$ was found in Tahura $\left(H^{\prime}=2.6\right)$ and the lowest value was in Southern Palu Park ( $\left.H^{\prime}=1.97\right)$.
\end{abstract}

Keywords: Biodiversity index, birds community, green open spaces

\section{ABSTRAK}

Ruang terbuka hijau (RTH) dapat berfungsi sebagai habitat bagi komunitas burung di perkotaan. Bentuk atau tipe RTH bervariasi sehingga diduga terdapat perbedaan komunits burung yang memanfaatkannya. Penelitian ini bertujuan mengidentifikasi komposisi komunitas burung dan menghitung indeks keanekaragaman jenis burung di lima RTH di Kota Palu. Penelitian dilakukan di RTH Hutan Kota, Taman hutan raya (Tahura), dan Taman Kota (Palu Barat, Palu Selatan dan Palu Timur). Pengumpulan data jenis burung dilakukan menggunakan metode titik hitung dengan radius $25 \mathrm{~m}$ dan jarak antar titik hitung $100 \mathrm{~m}$. Lama waktu pengamatan pada setiap titik hitung adalah 10 menit. Kondisi vegetasi pada setiap RTH diamati menggunakan metode jalur berpetak. Jumlah jenis burung yang berhasil dijumpai dari seluruh RTH yang diamati adalah sebanyak 58 jenis dari 31 famili, terdiri atas 44 jenis burung penetap dan 4 jenis burung migran. Di antara 58 jenis tersebut terdapat 10 jenis burung yang merupakan jenis endemik Sulawesi dan Walacea. Columbidae merupakan famili yang mendominansi RTH dengan anggota terbanyak yakni sebanyak sembilan jenis (15,5\%), diikuti famili Ardeidae dan Cuculidae masing-masing sebanyak empat jenis (6,9\%). Sebanyak empat jenis burung termasuk dalam kategori dilindungi berdasarkan PP No. 7 Tahun 1999 dan tercantum dalam Lampiran Permen LHK Nomor 106 Tahun 2018, yakni: Haliastur indus, Milvus migrans, Ardea sumatrana, dan Loriculus stigmatus. Di seluruh RTH yang diamati tidak ditemukan jenis-jenis burung yang terancam punah menurut IUCN, namun terdapat dua jenis burung yang tercantum dalam Appendix II CITES (Convention on International Trade in Endangered Species of Wild Fauna and Flora), yakni Haliastur indus dan Milvus migrans. Indeks keanekaragaman ( $\left.H^{\prime}\right)$ burung tertinggi dijumpai di Tahura Sulawesi Tengah dengan nilai $H^{\prime}=2,6$ sedangkan terendah di Taman Kota Palu Selatan dengan nilai $H^{\prime}=1,97$.

Kata kunci: indeks keanekaragaman, komunitas burung, ruang terbuka hijau

\section{PENDAHULUAN}

Burung menempati berbagai tipe habitat, baik hutan maupun bukan hutan (Alikodra 2002). Komunitas burung yang menempati suatu habitat dipengaruhi oleh faktor abiotik maupun biotik. Salah satu faktor yang mempengaruhi keanekaragaman burung dalam suatu komunitas adalah kondisi struktur vegetasi (Diaz 2006). Struktur vegetasi yang kompleks dan heterogen diduga memiliki keanekaragaman jenis burung yang tinggi. Hal ini sesuai dengan pernyataan Johnsingh dan Joshua (1994) bahwa struktur vegetasi merupakan kunci penentu keanekaragaman burung pada skala lokal. Struktur dan komposisi vegetasi pada suatu areal merupakan komponen penting bagi kehidupan burung, yakni sebagai tempat tinggal, beristirahat, mencari pakan, berlindung dari predator, dan berkembang biak (Lancaster dan Rees 1979; Campos et al. 2009). Karakteristik dan kerapatan 
vegetasi merupakan hal yang sangat penting dalam kaitannya dengan distribusi spesies burung, yang secara tidak langsung menunjukkan ketersediaan pakan (Lancaster dan Rees 1979).

Ruang terbuka hijau (RTH) perkotaan merupakan bagian dari ruang terbuka perkotaan yang berisi tumbuhan alami, tanaman budidaya, dan vegetasi hijau lainnya yang memberikan manfaat bagi kesehatan, rasa aman dan nyaman, serta memberikan nilai estetika (Groenewegen et al. 2006). Menurut Mardiastuti (2016), ruang terbuka hijau perkotaan umumnya tidak memiliki hamparan vegetasi alami dan berukuran kecil, tetapi dapat berfungsi sebagai habitat alternatif yang baik bagi burung. Pada umumnya, jenis-jenis burung yang menghuni kawasan ruang terbuka hijau adalah jenis-jenis burung generalis (Prasetyo 2017), yakni jenis burung yang mampu beradaptasi terhadap perubahan vegetasi.

Sebelum kejadian tsunami bulan September 2018, di wilayah Kota Palu terdapat berbagai macam ruang terbuka hijau, yang tersebar di Kecamatan Palu Barat, Palu Selatan dan Palu Timur. Selain itu terdapat RTH Kota Palu berupa Hutan Kota, Taman Kota, Tahura, taman pemakaman, dan jalur hijau. Keberadaan ruang terbuka hijau di Kota Palu ini diduga menjadi habitat bagi berbagai jenis satwa, termasuk burung.
Ancaman kepunahan jenis-jenis burung yang menempati ruang terbuka hijau perkotaan tergolong tinggi akibat hilangnya habitat, perburuan tanpa izin, dan pencemaran lingkungan. Oleh karena itu perlu dilakukan upaya dan tindakan konservasi burung pada ekosistem perkotaan. Salah satu upaya konservasi yang dapat dilakukan adalah penelitian komunitas burung di ruang terbuka hijau perkotaan. Hal ini menjadi penting, karena penelitian tentang keanekaragaman hayati, terutama jenis burung, umumnya lebih banyak dilakukan di ekosistem alam dibanding dengan pada ekosistem perkotaan (McKinney 2002; Beninde et al. 2015). Informasi tentang komunitas burung yang menempati habitat RTH dapat digunakan sebagai salah satu bahan pertimbangan dalam menetapkan prioritas pengelolaan habitat burung di Kota Palu.

\section{METODE PENELITIAN}

Pengambilan data dilakukan pada periode 28 Juli hingga 25 Agustus 2018. Penelitian dilaksanakan di lima RTH di Kota Palu, meliputi Kecamatan Palu Barat, Palu Selatan dan Palu Timur (Gambar 1). Luas masingmasing RTH dapat dilihat pada Tabel 1.

Tabel 1 Luas setiap RTH Kota Palu

\begin{tabular}{lcccc}
\hline Ruang Terbuka Hijau & & Luas lahan per kecamatan (ha) & Jumlah (ha) \\
& Palu Barat & Palu Selatan & Palu Timur & 4,0 \\
Hutan Kota & - & - & 4,0 & $4.405,32$ \\
Tahura & - & - & $4.405,32$ & 4,12 \\
Taman Kota & 0,72 & 1,2 & 2,2 & $4.413,44$ \\
\hline Total & 0,72 & 1,2 & $4.411,52$ & \\
\hline
\end{tabular}

Sumber: Peraturan Daerah Kota Palu (2011)

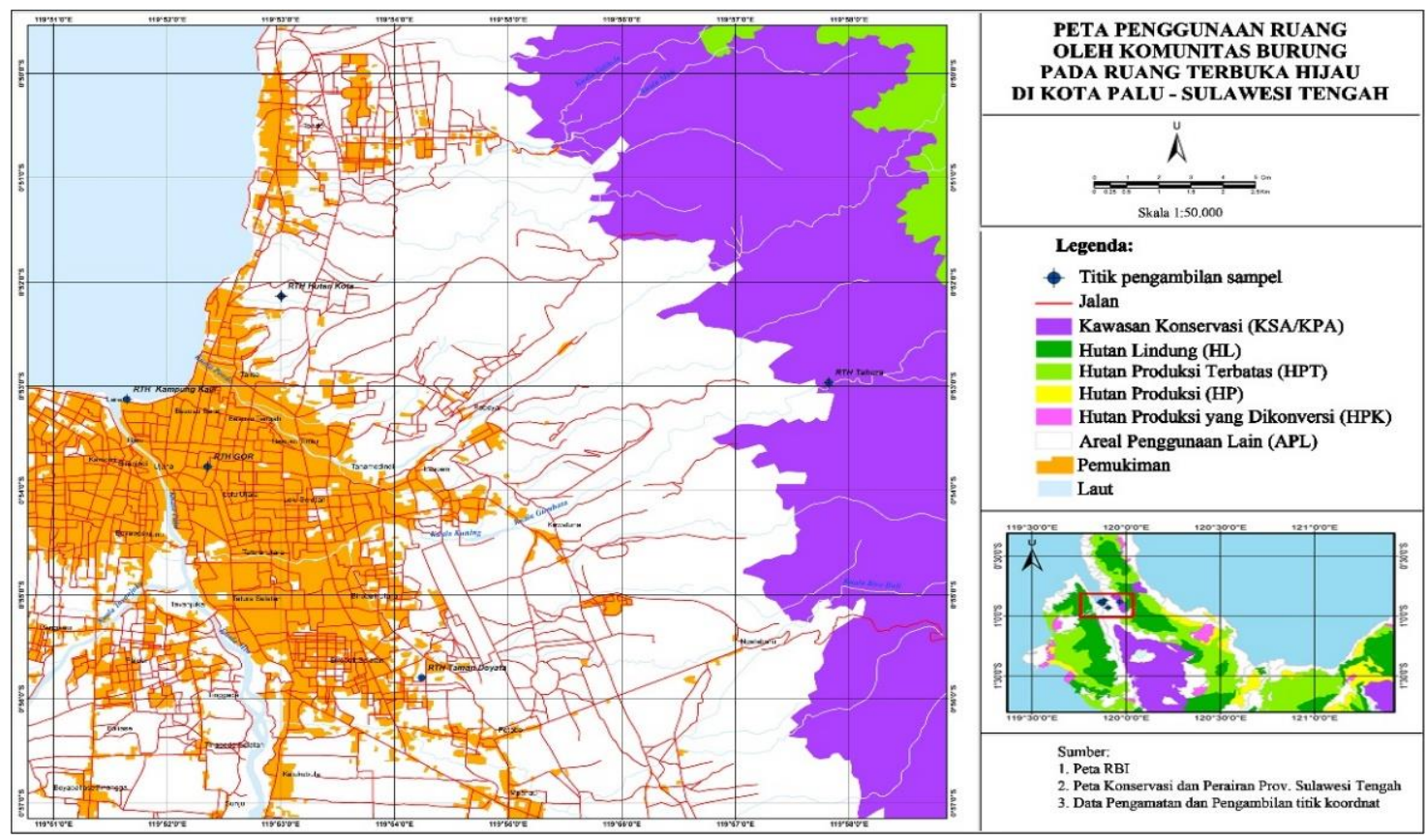

Gambar 1 Peta lokasi penelitian 
Pengambilan data tumbuhan untuk analisis habitat dilakukan dengan menggunakan metode petak tunggal (Soerianegara dan Indrawan 2008). Pada setiap tipe RTH ditempatkan satu unit contoh pengamatan tumbuhan. Petak pengamatan berukuran $20 \mathrm{~m}$ x $20 \mathrm{~m}$ untuk mengamati vegetasi tingkat pertumbuhan pohon selanjutnya dibagi-bagi secara bertingkat menjadi petakpetak berukuran $10 \mathrm{~m} \times 10 \mathrm{~m}$ untuk pengamatan tingkat pertumbuhan tiang (poles), $5 \mathrm{~m} \times 5 \mathrm{~m}$ untuk tingkat pertumbuhan pancang, dan $2 \mathrm{~m} \times 2 \mathrm{~m}$ untuk tingkat pertumbuhan anakan dan tumbuhan bawah (Gambar 2). Data keanekaragaman tumbuhan yang dikumpulkan meliputi nama jenis tumbuhan, diameter batang setinggi dada $( \pm 130 \mathrm{~cm}$ di atas tanah), jumlah individu setiap jenis yang ditemukan, tinggi bebas cabang, tinggi total. Pengukuran diameter batang setinggi dada hanya dilakukan terhadap tingkat pertumbuhan tiang dan pohon.

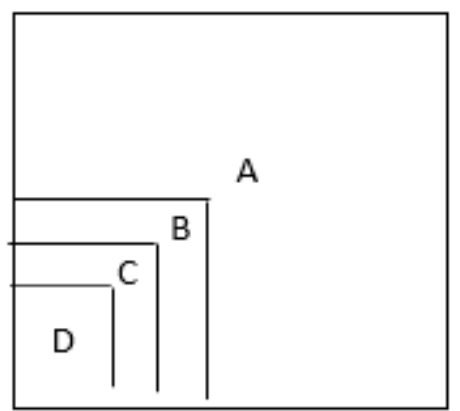

Gambar 2 Skema petak contoh pengamatan vegetasi di area $\mathrm{RTH}$; Petak $\mathrm{A}=$ tingkat pohon, $\mathrm{B}=$ tingkat tiang, $\mathrm{C}=$ tingkat pancang, $\mathrm{D}=$ tingkat anakan

Pengambilan data burung dilakukan melalui pengamatan langsung, yakni dengan melihat secara langsung individu burung pada suatu habitat (Bibby et al.
2000). Identifikasi spesies secara visual didasarkan pada buku panduan lapangan burung-burung di kawasan Wallacea. Data yang dikumpulkan meliputi nama jenisjenis burung dan jumlah individu setiap jenis burung yang teramati pada masing-masing tipe habitat.

Pengambilan data jenis dan jumlah individu setiap jenis burung dilakukan dengan menggunakan metode point count (titik hitung). Pengamatan dilakukan pada periode pagi hari antara pukul 05.30-10.00 WITA dan sore hari antara pukul 15.00-18.00 WITA. Pengamatan pada setiap tipe habitat (ruang terbuka hijau) dilakukan pada unit contoh (titik hitung) berbentuk lingkaran dengan radius $r=25 \mathrm{~m}$. Jarak antar titik hitung yang satu dengan lainnya adalah $100 \mathrm{~m}$ (Gambar 3). Di setiap habitat dibuat sebanyak empat titik hitung. Alokasi waktu pengamatan pada setiap titik hitung adalah 10 menit. Jumlah ulangan pengamatan sebanyak tiga kali ulangan. Salah satu habitat yaitu RTH Tahura memiliki luasan yang lebih luas dibandingkan dengan RTH lainnya karena sebagian besar wilayah Tahura ini termasuk wilayah Kabupaten Sigi, sehingga penempatan plot sampling di letakan di wilayah RTH Tahura Kota Palu yang memiliki kondisi fisik ekologi yang menjadi patokan peletakan plot sampling dan jumlah titik hitung yang diseragamkan.

Pengumpulan data penyebaran vertikal spesies burung pada setiap stratum tajuk pohon dilakukan dengan cara mencatat posisi spesies burung yang teramati. Selain itu alat klinometer digunakan untuk mengukur sudut elevasi antar garis datar tersebut dengan titik puncak dan aplikasinya untuk mengukur tinggi strata tajuk yang digunakan oleh jenis-jenis burung (Tabel 2). Pembagian strata tajuk mengacu pada van Balen (1984).

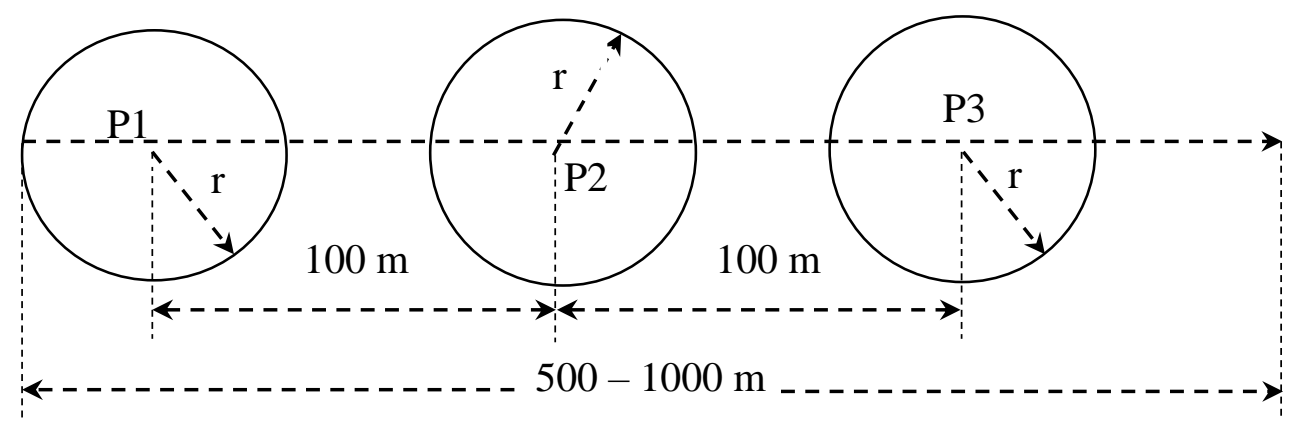

Gambar 3 Bentuk unit contoh metode Point count untuk burung.

Tabel 2 Pembagian stratum pemanfaatan ruang secara vertikal (van Balen 1984)

\begin{tabular}{lc}
\hline Kriteria & Ketinggian (m) \\
\hline Strata E (lantai hutan/tanah) & $0,00-0,15$ \\
Strata D (semak-semak rendah dan sedang) & $0,15-1,80$ \\
Strata C (semak-semak tinggi) & $1,80-4,50$ \\
Strata B (pohon di bawah tajuk) & $4,50-15,00$ \\
Strata A (pohon di atas tajuk) & $>15,00$ \\
\hline
\end{tabular}


Kekayaan jenis (species richness) dihitung menggunakan indeks kekayaan jenis Margalef $\left(D_{\mathrm{Mg}}\right)$. Persamaan indeks kekayaan jenis tersebut adalah sebagai berikut (Magurran 1988):

$$
D_{M g}=\frac{\left(\mathrm{S}-\mathbb{1}_{d}^{\mathbb{S}}\right.}{\operatorname{Ln} \mathbb{X}}
$$

Keterangan: $D_{\mathrm{Mg}}=$ indeks kekayaan jenis Margalef, $\mathrm{S}=$ jumlah jenis, $\mathrm{N}=\mathrm{Jumlah}$ seluruh individu yang ditemukan.

Keanekaragaman jenis burung di suatu habitat tertentu merupakan nilai yang menggabungkan kekayaan dengan kemerataan jenis. Dalam penelitian ini keanekaragaman jenis dihitung menggunakan indeks Shannon-Wiener (H') sebagai berikut (Magurran 1988):

Keterangan:

$$
H^{s}=\Sigma \frac{n i}{N} \ln \frac{n i}{N}=-\Sigma P i \ln P i
$$

$\mathrm{H}^{\prime}$ = indeks keanekaragaman Shannon,

$\mathrm{p}_{\mathrm{i}}=$ proporsi kelimpahan individu jenis ke-i terhadap kelimpahan seluruh jenis yang dihitung menggunakan persamaan $\mathrm{n}_{\mathrm{i}} / \mathrm{N}$,

$\mathrm{n}_{\mathrm{i}}=$ jumlah individu spesies ke-i,

$\mathrm{N}=$ jumlah seluruh individu dari spesies ke- $\mathrm{i}=\square \mathrm{n}_{\mathrm{i}}$.

Kemerataan (evenness) menyatakan komposisi proporsi jumlah individu setiap jenis yang ditemukan pada suatu habitat. Nilai indeks kemerataan (dinotasikan dengan E) berkisar antara 0 hingga 1. Proporsi kemerataan jenis burung pada setiap komunitas dihitung menggunakan indeks kemerataan Pielou dengan persamaan sebagai berikut (Magurran1988):

Keterangan:

$$
\mathrm{E}=\mathrm{H}^{\prime} / \ln \mathrm{S}
$$

$\mathrm{E}=$ indeks kemerataan,

$\mathrm{H}^{\prime}=$ indeks keanekaragaman Shannon

$\mathrm{S}=$ jumlah jenis.

Indeks kesamaan atau index of similarity diperlukan untuk mengetahui tingkat kesamaan antara beberapa unit sampling, atau beberapa komunitas yang dibandingkan komposisi dan struktur komunitasnya, yang dapat dihitung dengan indeks Jaccard ( $\left.\mathrm{I}_{\mathrm{SJ}}\right)$ (Magurran 1988), dengan rumus :

Indeks Kesamaan Jenis Jaccard $\left(\mathrm{I}_{\mathrm{SJ}}\right)=$

$$
\frac{a}{a+b+c}
$$

Keterangan :

$\mathrm{a}=$ Jumlah jenis yang umum di komunitas A dan B

$\mathrm{b}=$ Jumlah jenis yang umum di komunitas A tetapi tidak di komunitas B

$\mathrm{c}=$ Jumlah jenis yang umum di komunitas B tetapi tidak di komunitas A

Kriteria indeks kesamaan jenis Jaccard ( $\left.\mathrm{I}_{\mathrm{SJ}}\right)$ (Mueller-Dumbois dan Ellenberg 1974) mendekati 1 maka tingkat kesamaan tinggi. Jika $\left(\mathrm{I}_{\mathrm{SJ}}\right)$ mendekati 0 , maka menunjukan tingkat kesamaan rendah.

\section{HASIL DAN PEMBAHASAN}

\section{Kondisi Umum Ruang Terbuka Hijau}

\section{a. Hutan Kota Palu}

Hutan Kota Palu termasuk kawasan RTH Kota Palu yang terdapat di Kecamatan Palu Timur bertujuan sebagai zona konservasi, pendidikan dan pemberdayaan ekonomi lokal masyarakat. Hutan Kota Palu memiliki luas 4,0 ha, berada pada areal dengan ketinggian sekitar 57 mdpl, di areal Hutan Kota Palu terdapat tiga jenis pohon yang termasuk ke dalam tiga famili, yakni akasia (Acacia greggi), johar (Senna siamea), dan gamal (Gliricidia sepium). Keanekaragaman vegetasi di Hutan Kota Palu tergolong rendah, yakni dengan nilai indeks Shannon sebesar $H^{\prime}=0,51$. Namun demikian berdasarkan strata tajuk pohon maka di Hutan Kota ini memiliki strata yang lengkap, yakni dari tingkat E hingga tingkat stratum A. Tinggi pohon di areal Hutan Kota Palu berkisar antara 5-10 m. Akasia (A. greggi) merupakan salah satu jenis pohon yang termasuk dalam stratum $B$ dengan tinggi pohon $10 \mathrm{~m}$.

\section{b. Tahura Sulawesi Tengah}

Tahura Sulawesi Tengah memiliki ketinggian tempat sekitar 396 mdpl, di RTH ini ditemukan lima jenis vegetasi tingkat pohon, yakni: kemiri (Aleurites moluccanus), johar (S. siamea), malapoga (Cauropita guianensis), benoa (Octomeles sumatrana), dan gersen (Muntingia calabura). Indeks keanekaragaman jenis tumbuhan menurut Shannon di Tahura Sulawesi Tengah ini tergolong sedang, yakni $H^{\prime}=2,51$. Stratifikasi tajuk vegetasi tergolong lengkap, yakni terdapat lima strata tajuk dari stratum E hingga stratum A. Tinggi pohon berkisar antara 17-35 m. Malapoga (C. guianensis) dan kemiri (A. moluccanus) merupakan salah satu jenis pohon yang termasuk dalam stratum A dengan tinggi pohon maksimum $35 \mathrm{~m}$.

\section{c. Taman Kota Palu Selatan}

Taman Kota Palu Selatan pengelolaannya berada di bawah Pemerintah Kota Palu Provinsi Sulawesi Tengah. RTH ini memiliki ketinggian 101 mdpl. Kekayaan jenis tumbuhan pada tingkat pohon di RTH Taman Kota Palu Selatan tergolong rendah. Namun demikian, berdasarkan komposisi taksa tumbuhan maka RTH ini relatif lebih lengkap karena terdiri atas rerumputan, epifit, semak belukar dan tanaman hias. Jenis vegetasi tanaman hias yang dominan adalah bunga kupu-kupu (Bauhinia purpurea).

\section{d. Taman Kota Palu Timur}

Taman Kota Palu Timur memiliki dengan ketinggian sekitar 2,5 mdpl. Vegetasi yang menyusun stratifikasi tajuk RTH Taman Kota Palu Timur terdiri atas empat jenis tumbuhan, yakni angsana (Pterocarpus indicus), beringin (Ficus benjamina), palem (Arecaceae), dan asam (Tamarindus indica). Tinggi pohon berkisar antara 7-26 m. Angsana (P. indicus) merupakan spesies 
pohon yang termasuk dalam strata A dengan tinggi terbesar mencapai $26 \mathrm{~m}$.

\section{e. Taman Kota Palu Barat}

Taman Kota Palu Barat memiliki ketinggian tempat sekitar $3 \mathrm{mdpl}$, nilai Indeks keanekaragaman jenis tumbuhan tergolong rendah, yakni hanya mencapai $\mathrm{H}^{\prime}=0,25$. Stratifikasi tajuk di RTH Taman Kota Palu Barat terdapat lima strata tajuk yaitu stratum E hingga stratum A. Tinggi pohon berkisar antara 11-24 m. Cemara udang (Casuarina equisetifolia) dan Trembesi (Samanea saman) merupakan jenis pohon yang termasuk dalam stratum A dengan tinggi pohon maskimum $24 \mathrm{~m}$.

\section{Keanekaragaman dan Komposisi Jenis Burung}

Sebanyak 58 jenis burung dari 31 famili dijumpai selama penelitian. Famili columbidae merupakan famili dengan anggota terbanyak sembilan jenis (15,5\%). Indeks kekayaan jenis tertinggi dan keanekaragaman tertinggi dijumpai di Tahura Sulawesi Tengah (DMg = 9,94: $\left.\mathrm{H}^{\prime}=2,62\right)$, dan indeks kemerataan tertinggi diperoleh di Hutan Kota Palu $(\mathrm{E}=0,79)$. Indeks kekayaan jenis terendah didapatkan di Taman Kota Palu Timur $(\mathrm{DMg}=4,59)$ dan indeks keanekaragaman terendah didapatkan di Taman Kota Palu Selatan yang juga memiliki indeks kemerataan terendah $\left(\mathrm{H}^{\prime}=1,97: \mathrm{E}\right.$ $=0,60)$ (Tabel 3).

\section{a. Kekayaan jenis burung}

Kekayaan jenis burung di seluruh RTH Kota Palu adalah sebanyak 58 spesies. Berdasarkan indeks kekayaan Margalef $\left(D_{\mathrm{Mg}}\right)$ maka kekayaan jenis tersebut berkisar antara 4,59-9,94. RTH Tahura Sulawesi Tengah memiliki nilai indeks kekayaan jenis tertinggi $\left(D_{\mathrm{Mg}}=9,94\right)$ sedangkan RTH Taman Kota Palu Timur memiliki indeks kekayaan jenis terendah $\left(\mathrm{D}_{\mathrm{Mg}}=4,59\right)$.

Ruang terbuka hijau Tahura Sulawesi Tengah memiliki kekayaan jenis yang tinggi dibandingkan empat
RTH lainya karena RTH tahura memiliki area yang luas dan memiliki keanekaragaman jenis pohon yang tinggi dan vegetasi yang cukup baik. Menurut Dewi et al. (2007) habitat yang memiliki jenis vegetasi yang beragam akan menyediakan jenis pakan yang juga beragam sehingga pilihan pakan bagi burung akan lebih banyak. Faradila dan Sjarmidi (2012) menyatakan bahwa kekayaan spesies burung akan semakin tinggi apabila habitat semakin berhutan, dan sebaliknya kekayaan spesies burung akan semakin rendah apabila habitat semakin terbuka.

Rendahnya kekayaan spesies burung di lokasi ini, diduga karena adanya ancaman yang tinggi terhadap kehidupannya. Kekayaan jenis yang rendah juga disebabkan oleh respon burung terhadab habitat yang di tempati. Kerapatan bangunan di lokasi RTH akan menurunkan kekayaan jenis burung di habitat tersebut dan sebaliknya semakin berkurang bangunan di area tersebut maka kekayaan jenis burung akan meningkat. Karakteristik dan kondisi habitat akan mempengaruhi perbedaan dalam kehadiran dan jumlah individu spesies burung tersebut terhadap habitatnya.

\section{b. Keanekaragaman jenis}

Keanekaragaman jenis burung yang ditemukan di RTH Tahura Sulawesi tengah memiliki jumlah jenis yang tinggi sehingga nilai keanekaragaman di area ini cukup tinggi. Sesuai nilai indek keanekaragaman burung di RTH Tahura menurut Shannon yaitu $\mathrm{H}^{\prime}=2,62$ dan keanekaragaman tumbuhan $\mathrm{H}^{\prime}=2,51$. Kondisi tersebut dapat diasumsikan karena ketersediaan sumber hidup seperti pakan, tempat berlindung dan berkembang biak yang cukup bagi spesies-spesies burung yang ditemukan di area ini. Tingginya keanekaragaman jenis burung pada $\mathrm{RTH}$, disebabkan oleh faktor ketersediaan makanan dan kompleksitas vegetasi.

Tabel 3 Kekayaan (DMg), keragaman (H'), dan kemerataan (E) jenis burung di RTH Kota Palu

\begin{tabular}{lccccc}
\hline RTH Kota Palu & Luas $(\mathrm{Ha})$ & Jenis Burung & $D_{M g}$ & $\mathrm{H}^{\prime}$ & $\mathrm{E}$ \\
\hline Hutan Kota Palu & 4 & 23 & 5,63 & 2,46 & 0,79 \\
Tahura Sulawesi tengah & $4.405,32$ & 34 & 9,94 & 2,62 & 0,74 \\
Taman Kota Palu Barat & 0,72 & 24 & 4,72 & 2,02 & 0,64 \\
Taman Kota Palu Selatan & 1,2 & 26 & 5,38 & 1,97 & 0,6 \\
Taman Kota Palu Timur & 2,2 & 19 & 4,59 & 2,21 & 0,75 \\
\hline
\end{tabular}

Tabel 4 Indeks keanekaragaman jenis $\left(\mathrm{H}^{\prime}\right)$ jenis pohon pada RTH Kota Palu

\begin{tabular}{lcc}
\hline RTH Kota Palu & Jumlah jenis pohon & H' \\
\hline Hutan Kota Palu & 3 & 0,51 \\
Tahura Sulawesi Tengah & 5 & 2,51 \\
Taman Kota Palu Barat & 2 & 0,25 \\
Taman Kota Palu Timur & 4 & 1,74 \\
\hline
\end{tabular}


Nilai keanekaragaman jenis pohon pada RTH Tahura memiliki nilai lebih tinggi dibandingkan nilai RTH yang lain, Beberapa penelitian menunjukkan, bahwa keanekaragaman jenis burung di suatu tipe habitat, dipengaruhi oleh faktor kompleksitas vegetasi dalam suatu habitat (Karr dan Roth 1971), tingkat kepadatan pohon (Chettri et al. 2005), volume vegetasi (Mills et al. 1991), struktur tajuk (Pearson 1975; Patterson et al. 1995), komposisi vegetasi (Sanchez et al. 2015) dan ketersediaan makanan (Marsden dan Pilgrim, 2003). Karr (1975) keanekaragaman jenis burung pada komunitas mempunyai korelasi dengan sumber daya alam.

RTH Taman Kota Palu Selatan memiliki nilai indeks keanekaragaman jenis burung terendah $\mathrm{H}^{\prime}=1,97$ dari empat RTH lainnya. Rendahnya keanekaragaman burung di lokasi ini karena kurangnya vegetasi dan sumber pakan yang kurang di lokasi ini. Selain itu keberadaan burung pada suatu habitat sangat erat hubungannya dengan faktor-faktor fisik lingkungan seperti tanah, air, temperatur, cahaya matahari, serta faktor-faktor biologis yang meliputi vegetasi dan satwa lainnya (Welty dan Baptisa 1988). Penggunaan habitat oleh burung akan berubah-ubah tergantung kondisi habitat yang menyediakan pakan. Secara umum dapat dikatakan bahwa kehadiran suatu jenis burung di habitat tertentu merupakan suatu seleksi, apakah habitat tersebut sesuai dengan kebutuhan hidupnya. Dengan kata lain burung akan memilih habitat yang mampu menyediakan kebutuhan hidup dan keadaan yang mendukung keberadaannya di habitat tersebut.

\section{c. Kemerataan Jenis}

Kota Palu pada lima RTH yaitu Hutan Kota Palu, Tahura Sulawesi Tengah, Taman Kota Palu Barat, Taman Kota Palu Selatan, Taman Kota Palu Timur ditemukan sebanyak 58 spesies dengan nilai indeks kemerataan berkisar antara (E) 0,60-0,79. Area RTH Hutan Kota Palu memiliki nilai indeks kemerataan tertinggi sebesar $(E=0,79)$ sedangkan pada RTH Taman Kota Palu Selatan memiliki nilai indeks kemerataan terkecil $(E=0,60)$. Kemerataan jenis burung yang tinggi terdapat di areal RTH Hutan Kota Palu, nilai kemerataan yang tinggi menunjukkan tidak ada jenis burung secara tunggal yang dominan (Wiens 1992). Nilai kemerataan ini dapat menunjukan kompetisi intra spesies yang tidak tinggi.

Kemerataan spesies tertinggi mempunyai keunikan, yaitu bahwa habitat RTH Hutan Kota Palu merupakan habitat dengan ketersediaan komponen habitat seperti pakan, tempat berlindung maupun tempat berkembang biak yang cukup dan seimbang bagi spesies-spesies burung karena ketersediaan pakan yang dibutuhkan oleh suatu jenis burung dapat diperoleh tidak pada hanya satu lokasi, tetapi pada sebagian besar wilayah. Nilai kemerataan yang rendah terdapat di RTH Taman Palu Selatan, rendahnya nilai kemerataan di lokasi ini menunjukan adanya kecenderungan dominansi spesies tertentu di suatu habitat.

\section{Komposisi Jenis}

Keanekaragaman burung di Indonesia berdasarkan catatan Burung Indonesia terbaru pada tahun 2017 memiliki jenis yang terus bertambah yaitu 1.769 jenis burung dibandingkan dari tahun 2016 sebanyak 1.672 jenis yang terindentifikasi berada di Tanah Air. Penambahan tersebut sebagian besar merupakan hasil pemisahan jenis yang sudah ada, karena adanya perbedaan morfologi, suara ataupun genetik berdasarkan hasil penelitian terbaru (Burung Indonesia 2017). Jenis burung endemik yang berada di Indonesia memiliki jumlah yang juga bertambah yakni sebelumnya 512 jenis kini menjadi 1.777 jenis burung endemik. Jenis sebaran burung yang terbatas teridentifikasi bahwa sebelumnya 395 jenis kini bertambah menjadi 448 jenis burung (Burung Indonesia 2017).

Sulawesi merupakan pulau yang sangat penting dalam menyumbang kekayaan burung di Indonesia. Indonesia memiliki 381 spesies burung endemik dengan 115 spesies di antaranya hidup di Sulawesi dan 96 spesies hanya di temukan di Pulau Sulawesi (Andrew 1992). Holmes dan Philips (1999) lebih lanjut menjelaskan bahwa burung endemik Sulawesi berjumlah 97 spesies, dengan memasukan Caprimulgus celebensis dalam daftarnya. Jumlah ini jauh lebih banyak dibandingkan dengan jumlah burung endemik di pulaupulau lain di seluruh Indonesia.

Komposisis jenis burung RTH Kota Palu Sulawesi Tengah terdapat 11 jenis burung endemik Sulawesi yaitu Lalage sueurii, Turacoena manadensis, Coracias temminckii, Rhamphococcyx calyorhynchus, Dicaeum vulneratum, Dicaeum aureolimbatum, Lonchura pallida, Loriculus stigmatus, Streptocitta albicollis, Scissirostrum dubium, dan Trichastoma celebense. Empat jenis burung migran yaitu Todirampus sanctus, Motacilla cinerea, Motacilla flava, Actitis hypoleucos. Selain itu Berdasarkan status konservasinya, terdapat empat jenis burung yang dilindungi berdasarkan Permen KLHK No 106 Tahun 2018 yaitu Haliastur indus, Milvus migrans, Ardea sumatrana, Loriculus stigmatus.

Burung yang mendominasi per individu yaitu jenis Passer montanus dan Aerodramus vanikorensis. Burung $P$ montanus dari famili Paseridae terlihat tidak hanya bertengger di pepohonan tetapi juga bertengger di atap bagunan maupun mencari makan di rerumputan taman kota. Menurut MacKinnon dan van Balen (1998) $P$. montanus merupakan jenis burung yang dapat ditemukan di daerah perkotaan karena menyukai habitat yang terbuka, sehingga dapat dengan mudah ditemukan di lokasi penelitian.

\section{Guild}

Terdapat lima tipe guild yaitu frugivora $(12,50-$ $42,11 \%)$, granivora $(8,82-29,63 \%)$, insektivora aerial $(7,41-16,67 \%)$, insektivora arborial $(16,67-41,18 \%)$, 
karnivora $(8,70-29,17 \%)$, nectarivora $(2,94-10,53 \%)$ (Gambar 4).

Tipe guild insektivora arboreal yang mendominasi pada setiap RTH. Tipe guild insektivora yang hadir di RTH menandakan tersedianya sumberdaya pakan berupa serangga. Tipe guild insektivora aerial ditemukan di tiap RTH namun nilai presentase yang diperoleh tidak setingi tipe guild arboreal. Jenis burung dari tipe guild ini lebih menyukai habitat terbuka dibandingkan hutan dengan tutupan yang rapat (English et al. 2016).

Selain itu Tipe guild yang mendominasi pada Taman Kota Palu Timur adalah guild frugivora. Keberadaan tipe guild ini dipengaruhi oleh ketersediaan buah sebagai pakan utamanya yang tersedia di sekitar area RTH ini. Ketersediaan dan kelimpahan buah tergantung pada kondisi musim dan cuaca (Blake dan Loiselle 2000).

\section{Kesamaan Komunitas Burung}

Indeks kesamaan komunitas berkisar antara $\left(\mathrm{I}_{\mathrm{SJ}}\right)$ 0,24 - 0,52 (Gambar 5). Area RTH Hutan Kota Palu dan RTH Taman Kota Palu Selatan memiliki nilai indeks kesamaan tertinggi sebesar $\left(\mathrm{I}_{\mathrm{SJ}}\right)=0,52$ sedangkan pada area RTH Tahura Sulawesi Tengah dan Taman Kota Palu Barat memiliki nilai indeks kesamaan terkecil $\left(\mathrm{I}_{\mathrm{SJ}}\right)=0,24$ lebih jelasnya dapat dilihat pada (Tabel 5).

Nilai kesamaan komunitas burung yang berbeda jauh menunjukkan bahwa kondisi lingkungan pada masing-masing habitat yang dibandingkan relatif heterogen sehingga keberadaan jenis burung pada masing-masing lokasi memiliki karakteristik yang cukup khas. Komunitas burung pada habitat yang berbeda berhubungan dengan distribusi burung yang dipengaruhi kesesuaian habitatnya meliputi adaptasi burung terhadap lingkungan, kompetisi, strata vegetasi, ketersediaan pakan, seleksi alam dan faktor dari alam lainnya (Alikodra 2002). Banyak faktor habitat yang mirip di antara RTH Kota Palu, seperti keberadaan pohon, kanopi, penutupan tanah serta keberadaan air baik permanen maupun tidak merupakan komponen habitat yang menjadi pemicu kehadiran spesies burung.

\section{Penyebaran Vertikal Spesies Burung pada Ruang Terbuka Hijau Kota Palu}

Komunitas burung pada RTH Kota Palu menyebar pada tajuk atas sampai lantai hutan. Penggunaan ruang stratifikasi tajuk jenis-jenis burung di kelima lokasi RTH ditemukan strata tajuk B paling banyak digunakan, nilai presentase yang diperoleh berkisar 40,74 - 75,00 selanjutnya nilai persentase stratifikasi tajuk A yang digunakan jenis burung berkisar 26,09 - 50,00, nilai strtifikasi pada tajuk C berkisar 11,76 - 22,22, pada stratifikasi tajuk D berkisar $0,00-12,50$ dan nilai stratifikasi tajuk E berkisar 5,26 - 14,81 (Gambar 6).

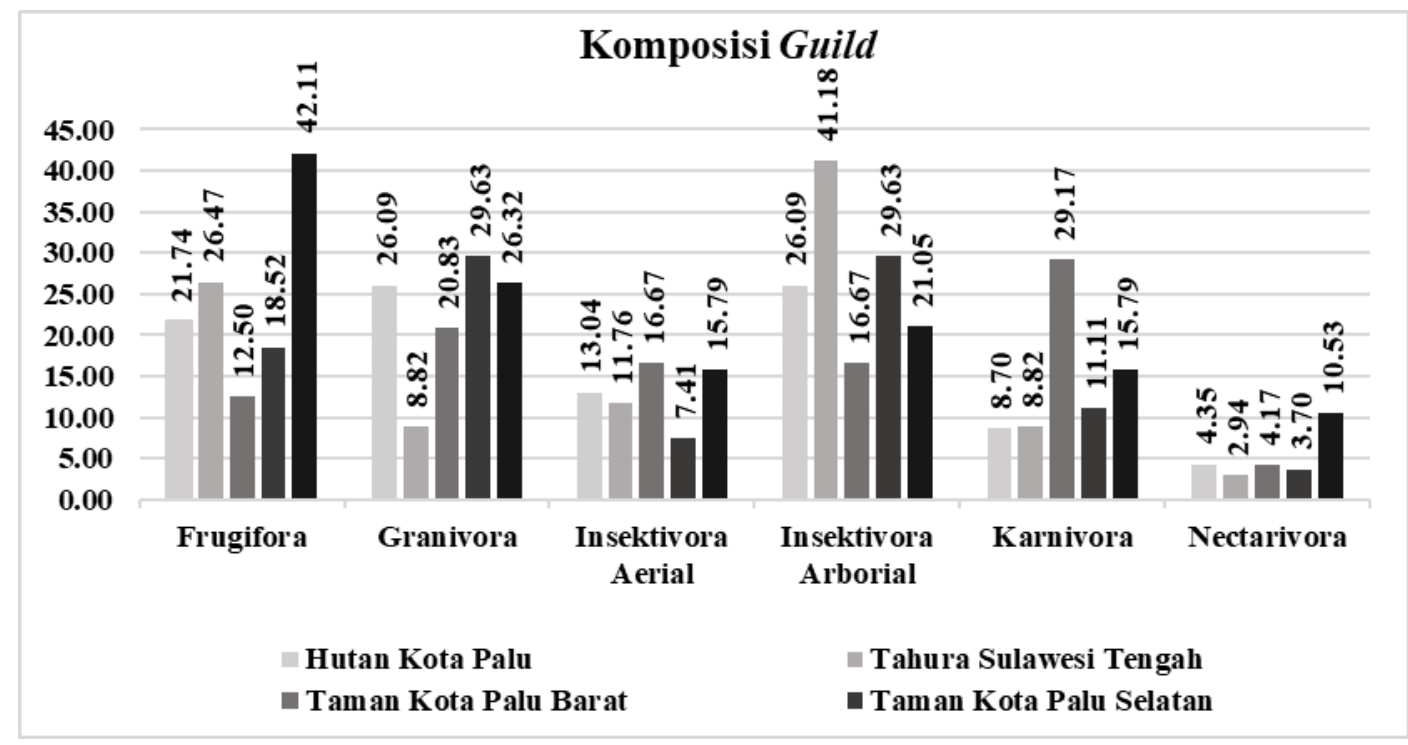

Gambar 4 Persentase Komposisi Guild

Tabel 5 Matriks indeks kesamaan jenis antara tipe habitat RTH di Kota Palu.

\begin{tabular}{lcccc}
\hline RTH Kota Palu & $\begin{array}{c}\text { Tahura Sulawesi } \\
\text { Tengah }\end{array}$ & $\begin{array}{c}\text { Taman Kota Palu } \\
\text { Barat }\end{array}$ & $\begin{array}{c}\text { Taman Kota } \\
\text { Palu Selatan }\end{array}$ & $\begin{array}{c}\text { Taman Kota } \\
\text { Palu Timur }\end{array}$ \\
\hline Hutan Kota Palu & 0,39 & 0,43 & 0,52 & 0,5 \\
Tahura Sulawesi Tengah & & 0,24 & 0,33 & 0,27 \\
Taman Kota Palu Barat & & & 0,38 & 0,44 \\
Taman Kota Palu Selatan & & & & 0,39 \\
\hline
\end{tabular}




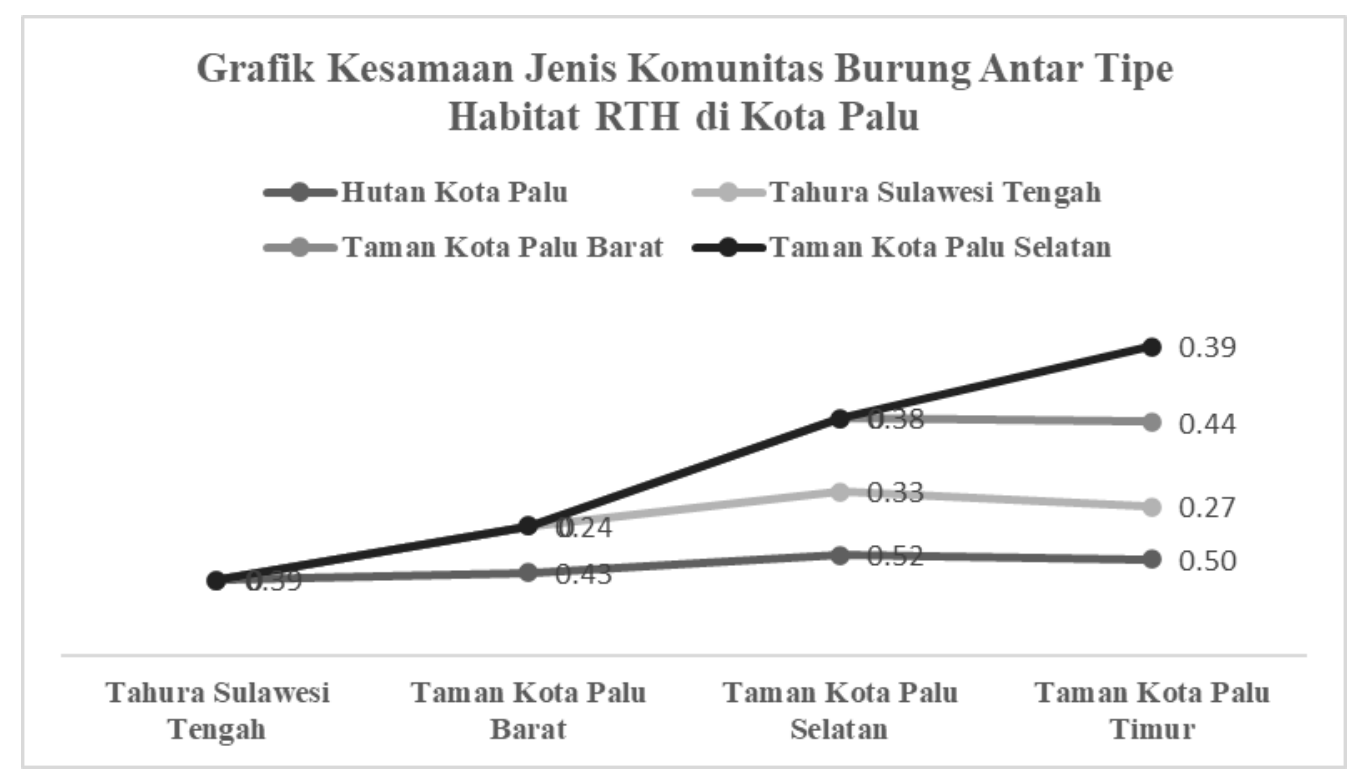

Gambar 5 Kesamaan Jenis Komunitas Burung Antar Tipe RTH di Kota Palu

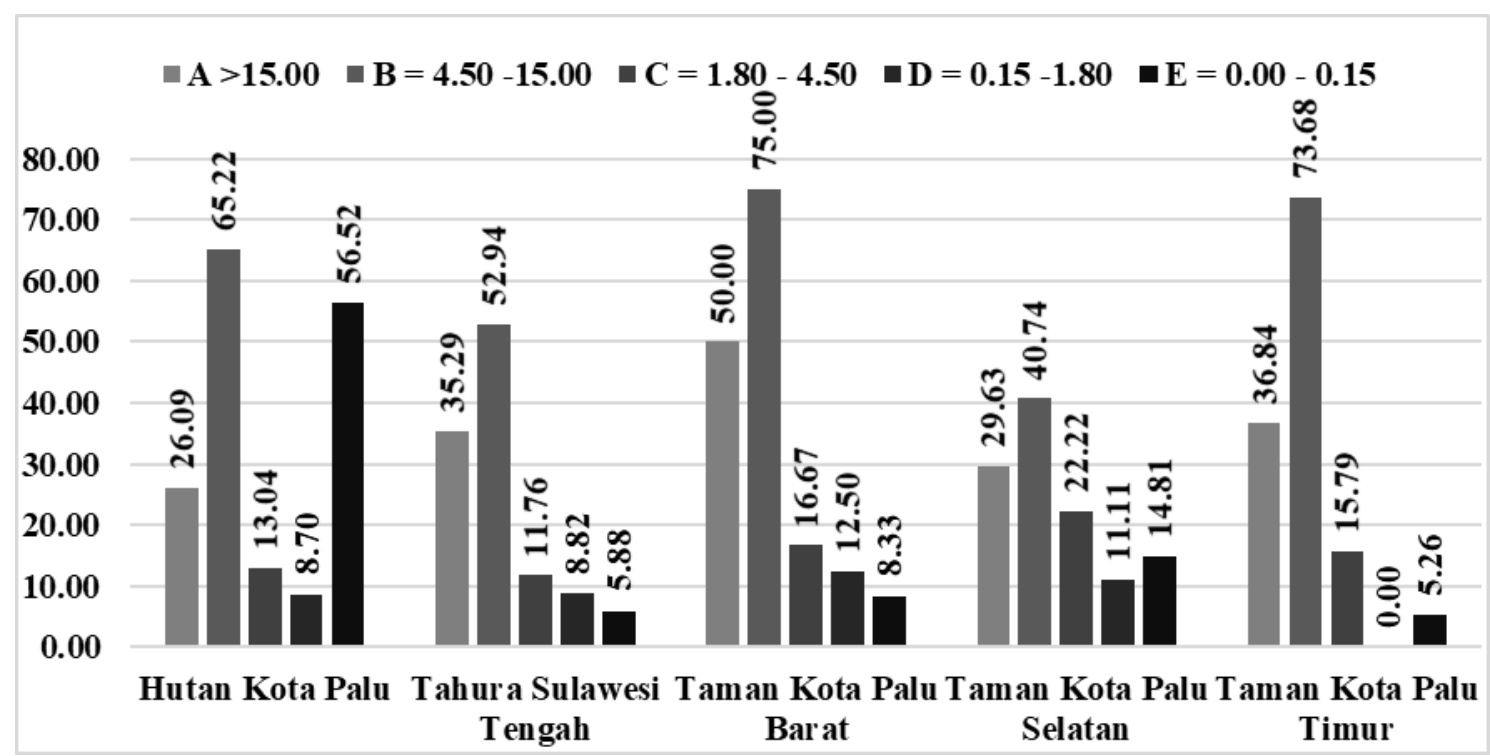

Gambar 6 Persentase Penggunaan stratifikasi RTH di Kota Palu.

Pola penyebaran burung secara vertikal menunjukkan bahwa penyebaran jenis-jenis burung berkaitan secara ekologi antara jenis burung dengan kebutuhan pakan yang terdapat pada stratum tersebut. RTH Kota Palu terdapat 58 jenis burung yang menggunakan lima strata tajuk. Strata tajuk yang paling sering digunakan yaitu strata B. Menurut Dewi et al. (2007), penggunaan strata vegetasi oleh burung memiliki hubungan dengan ketersediaan pakan dan ruang pada strata tersebut. Pada strata B, pakan burung (buah, bunga dan serangga) terdapat dalam jumlah yang melimpah, sehingga banyak jenis burung yang memanfaatkan strata tersebut.

Burung menggunakan strata vegetasi diduga dipengaruhi oleh sumber makanan, tempat bersarang dan berlindung dari predator. Menurut Peterson (1980) Penyebaran secara vertikal burung sangat dipengaruhi oleh kesesuaian tempat hidup burung, meliputi adaptasi burung terhadap lingkungan, kompetisi, strata vegetasi, ketersedian pakan dan seleksi alam.

\section{SIMPULAN}

Terdapat 58 spesies burung yang teridentifikasi di RTH Kota Palu dengan 31 famili. sebanyak 11 jenis di antaranya jenis endemik Sulawesi, empat jenis atau di antaranya merupakan jenis burung yang dilindungi berdasarkan Permen LHK Nomor 20 Tahun 2018. Tahura Sulawesi Tengah memiliki kekayaan jenis tertinggi $\left(D_{\mathrm{Mg}}=9,93\right)$ dengan indeks keanekaragaman 
Shannon tertinggi $\left(\mathrm{H}^{\prime}=2,62\right)$ dibanding dengan tipe RTH lainnya. Kesamaan komunitas burung di Tahura dengan RTH lainnya sangat rendah, yakni dibawah 0,5. Stratifikasi tajuk jenis-jenis burung di kelima lokasi RTH ditemukan strata tajuk B paling banyak digunakan, nilai presentase yang diperoleh berkisar 40,74 - 75,00 selanjutnya nilai persentase stratifikasi tajuk A yang digunakan jenis burung berkisar 26,09 - 50,00, nilai strtifikasi pada tajuk C berkisar 8,70 - 22,22, pada stratifikasi tajuk $\mathrm{D}$ berkisar $0,00-12,50$ dan nilai stratifikasi tajuk E berkisar 5,26 - 14,81.

\section{DAFTAR PUSTAKA}

Alikodra HS. 2002. Pengelolaan Satwa Liar. Jilid I. Bogor: Fakultas Kehutanan Institut Pertanian Bogor.

Andrew P. 1992. The birds of Indonesia. Jakarta: Indonesian Ornithological Society.

Beninde J, Veith M, Hochkirch A. 2015. Biodiversity in cities needs space: a meta-analysis of factor determining intra-urban biodiversity variation. Ecol Lett. 1-12. doi:10.1111/ele.12427.

Bibby C, Jones M, Marsden S. 2000. Teknik-Teknik Ekspedisi Lapangan Survey Burung. Bogor: Bird life International-Indonesia Programme.

Blake JG, Loiselle BA. 2000. Diversity of birds along an elevational gradient in the Cordillera Central, Costa Rica. The Auk 117(3): 663-686.

Burung Indonesia. 2017. Infografis status burung di indonesia [Internet]. [di unduh 2018 maret 14]. Tersedia di http: // www. burung. org/ 2017/ 03/21/ infografis-status-burung-di-indonesia-2017/.

Campos DP, Bander LA, Raksi A, Blumstein DT. 2009. Perch exposure and predation risk: a comparative in passerines. Acta Ethol. 12:93-98.

Chettri N, Debes C, Eklabya S, Rodney J. 2005. The relationship between bird communities and habitat: a study a tekking corridor in the Ikkim Himalaya. Mt Res Dev. 25: 235-243.

Dewi RS, Y Mulyani, Y Santosa. 2007. Keanekaragaman jenis burung di beberapa tipe habitat Taman Nasional Gunung Ciremai [tesis]. Bogor: Institut Pertanian Bogor.

Diaz L. 2006. Influences of forest type and forest structure on bird communities in oak and pine woodlands in Spain. For Ecol Manage. 223:54-65.

English PA, Nocera JJ, Pond BA, Green DJ. 2016. Habitat and food supply across multiple spatial scales influence the distribution and abundance of nocturnal aerial insectivore. Landscape Ecol. DOI 10.1007/s10980-016-0454-y.

Fardila D, Sjarmidi A. 2012. Bird distribution along environmental gradients in North Bandung, West Java. Res J Sci (1): 23-32.

Groenewegen PP, van den Berg AE, de Vries S, Verheij RA. 2006. Vitamin G: effects of green space on

Peterson RT. 1980. Burung Pustaka Alam Life. Jakarta: Tiara Pustaka. health, well-being, and social safety. BMC Public Health 6(1):149.

Johnsingh AJT, Joshua J. 1994. Avifauna in three vegetation types on Mundanthurai Plateu. J Trop Ecol. 10:323-335.

Holmes D, Philips K. 1999. Burung-Burung di Sulawesi. Bogor: Puslitbang Biologi LIPI.

Karr JR, Roth RR. 1971. Vegetation structure and avian diversity in several New World Areas. Am Nat. 105:423- 435.

Karr JR. 1975. Production, energy pathways, and community diversity in forest birds. Trop Ecol Syst. (11), 161-176.

[KEMEN-LHK] Kemetrian Lingkungan Hidup dan Kehutanan. 2018. PERMEN LHK RI Nomor:P.106/Menlhk/Setjen/Kum. 1/6/2018: Tentang Jenis Tumbuhan dan Satwa DIlindungi. Indonesia: Peraturan Menteri Lingkungan Hidup dan Kehutanan Republik Indonesia.

Lancaster RK, Rees WE. 1979. Bird communities and the structure of urban habitats. Can $J$ Zool. 57:2358-2368.

Mackinnon JPK, van Balen B. 1998. Panduan lapangan Burung-Burung di Sumatra, Jawa, Bali dan Kalimantan. Bogor: Pustlitbang biologi-Lipi.

Magurran AE. 1988. Ecological Diversity and its Measurement. London: Princeton university press.

Mardiastuti A. 2016. Pengelolaan Burung Liar Pada Lansekap Yang Didominansi Manusia [orasi ilmiah]. Bogor: Institut Pertanian Bogor.

Marsden SJ, Pilgrim JD. 2003. Factors influencing the abundance of parrots and hornbills in pristine and disturbed forests on New Britain, PNG. Ibis. 145:45-53.

McKinney ML. 2002. Urbanization, biodiversity, and conservation: the impacts of urbanization on native species are poorly studied, but educating a highly urbanized human population about these impacts can greatly improve species conservation in all ecosystems. Bio Sci. 52(10):883-890.

Mills GS, Dunning JB, Jr., Bates JM. 1991. The relationship between breeding bird density and vegetation volume. Wilson Bull. 103:468-479.

Mueller-Dumbois D, Ellenberg H. 1974. Aims and Methods of Vegetation Ecology. New York: John Willey and Sons Inc.

Patterson IJ, Ollason JG, Doyle P. 1995. Bird populations in upland spruce plantations in Northern Britain. Agric Ecosyst Environ. 112:2140.

Pearson DL. 1975. The relation of foliage complexity to ecological diversity of three Amazonian bird communities. Condor. 77:453-466.

[PERDA] Peraturan Daerah Kota Palu. 2011. Tentang Rencana Tata Ruang Wilayah Kota Palu Nomor 16 Tahun 2010-2030. Palu (ID): Peraturan Daerah Kota Palu. 
Prasetyo LB. 2017. Pendekatan Ekologi Lansekap untuk Konservasi Biodiversitas. Bogor: Institut Pertanian Bogor.

Sanchez-Oliver JS, Rey Benayas JM, Carrascal LM. 2015. Low effect of young afforestations on bird communities inhabiting heterogeneosis miditerranean cropland. Perrrj. 1453: 1-12.

Soerianegara I, Indrawan A. 2008. Ekologi Hutan Indonesia. Bogor: Institut Pertanian Bogor. van Balen B. 1984. Bird Counts and Bird Observation in the Neighbourhood of Bogor. Wageningen: Nature Conservation, Department of Agriculture, University of Wageningan.

Welty JC, Baptista L. 1988. The life of birds. Philadelpihia: Saunders College Pub.

Wiens JA. 1992. The Ecology of Birds Communities Vol 1. Foundations and patterns. Cambridge: Cambridge University Press 